Trinity University

Digital Commons @ Trinity

Classical Studies Faculty Research

Classical Studies Department

2013

Orality, Folktales and the Cross-Cultural Transmission of Narrative

Lawrence Kim

Trinity University, lawrence.kim@trinity.edu

Follow this and additional works at: https://digitalcommons.trinity.edu/class_faculty

Part of the Classics Commons

Repository Citation

Kim, L. (2013). Orality, folktales and the cross-cultural transmission of narrative. In T. Whitmarsh \& S.

Thomson (Eds.), The romance between Greece and the East (pp. 300-321). Cambridge University Press.

This Contribution to Book is brought to you for free and open access by the Classical Studies Department at Digital Commons @ Trinity. It has been accepted for inclusion in Classical Studies Faculty Research by an authorized administrator of Digital Commons @ Trinity. For more information, please contact jcostanz@trinity.edu. 


\section{Orality, folktales and the cross-cultural transmission of narrative}

Lawrence Kim

\section{Introduction}

The last several decades have witnessed a renewed interest in exploring the remarkable similarities of motifs, plots and themes between Greco-Roman narrative and that of other ancient literary traditions (e.g., Egyptian, Persian, Jewish). If Euch commonalities are not coincidental or the result of independent development (and research indicates that they are not), it would be reasonable to raise the question of transmission, that is, by what means they passed from one culture to another. In the past, however, scholarly energies, caught up in the debate over the novel's origins, were more directed toward establishing the chronological priority of one narrative tradition (e.g., India, Egypt) over the others and less with the mechanics of actual cross-cultural transmission. ${ }^{1}$ Even in more recent work one finds a studied vagueness on the issue (understandable perhaps, given the relative lack of evidence); at best there seems to be a presumption that written texts, specifically translations, provided the means by which stories travelled from one culture to another. ${ }^{2}$ The purpose of this article, however, is to explore the possibility that such cross-cultural transmission in the Hellenistic and Imperial world could have occurred orally as well as through writing.

To outline some of the difficulties involved in such an inquiry, let us look at a particular case, taken from Lucian's Toxaris, a collection of tales about friendship, written in Greek around the mid to late second century CE. One story tells of three Scythian friends who go to extraordinary lengths to avenge an insult that one of them, Arsacomas, has suffered at the hands of the Bosporan king. Arsacomas had fallen in love with the king's daughter, Mazaea, but when he presented himself among her suitors, his poverty

${ }^{1}$ Winkler 1994.

2 See, e.g., Braun 1938, Anderson 1984, Dieleman and Moyer 2010. In periods for which we have more evidence - late antiquity and the medieval era - translation played a crucial role in disseminating novels like the Alexander Romance or Secundus the Silent Philosopher over a vast geographical area. 
was ridiculed by the king and his guests. His two friends now insist on helping him obtain revenge; while Arsacomas is raising an army to attack the Bosporans, one of his comrades manages to get the king alone, cuts off his head and escapes; the other steals Mazaea from her new husband, the king of the Machlyans, and presents her, still a virgin, to Arsacomas. In the battle that follows, the Scythians defeat the much larger forces of the Machlyans, the Bosporans, as well as the Sauromatians, all of whom are now commanded by Eubiotus, the brother of the Bosporan king, who has taken the throne after the latter's death (Tox. 44-55).

This short narrative of romance and adventure raises two initial questions. First of all, is it based on an authentically 'Scythian' tale, or is it just a Greek fiction about Scythians, ${ }^{3}$ crafted by Lucian or someone else? Second, is the tale somehow related to the Greek novel? The drama is precipitated by Arsacomas'. falling deeply in love with 'Mazaea, a tall and beautiful girl' upon seeing her at a banquet ('he fell in love, and was in a bad way', 44), and even though we never find out her feelings on the matter, the emphasis on love and virginity is unusual among the stories of male friendship told in the Toxaris. Moreover, the Greek novel known as Calligone is set in a comparable Scythian milieu: one papyrus fragment features the eponymous heroine, a Greek from the Black Sea city of Olbia, arguing vigorously with a man named Eubiotus as Sauromatian soldiers stand outside (cf. the Sauromatian commander of the same name in Toxaris). ${ }^{4}$

These ${ }_{\text {s }}$ light, but intriguing, correspondences have convinced some scholars that the two stories must be connected. ${ }^{5}$ For instance, in their commentary; on Calligone Susan Stephens and Jack Winkler tentatively propose a common source behind both tales, mapping out a plausible evolution from orally circulating Scythian/Sauromatian legend to written Greek narrative: there was 'at least one famous story, perhaps first popularised in legend and subsequently written down' which was 'transmitted by Greek writers'. (possibly by 'Greeks settled in the Thracian Bosporus') and 'served as a source for Lucian and [Calligone]. ${ }^{6}$ Given the scarcity of evidence, it is impossible to confirm or refute this thesis. But it is

3 As Anderson 2004: 22, notes, 'this evidence can only underline that the Greeks thought there was a Scythian oral tradition extending to tales, especially of heroic abduction and rescue... ' Cf. Ovid, Ex Ponto 3.2.59 $\rightarrow 0$.

4 PS $/ 8.98 \mathrm{I}$ (= Pack 2628); another fragment, P.Oxyined. 112/130(a), adds further details. See Stephens and Winkler 1995: 267-76, and Lopez Martínez 1998: 149.

5 Rostovtzeff 1931: vol. 1, 98-9; Stephens and Winkler 1995: 268-70; Stephens 1996: 666-7; Anderson 2004: 21-2 and 153-8; contra Morgan 1998: 3350-1. On the general novelistic feel of the Toxaris, see Anderson 1976: 12-33; Jones 1986: $56-8$.

${ }^{6}$ Stephens and Winkler 1995: 270. 
worth comparing it with how Lucian himself depicts the process of the tale's transmission. The Toxaris is a dialogue between a Greek, Mnesippus, and the eponymous Scythian, set somewhere in Greece and apparently in Lucian's own time. In order to settle a dispute about whether the Greeks honour friendship as much as the Scythians, Mnesippus and Toxaris each tell one another five 'contemporary' stories ( $\tau \tilde{\omega} \nu \kappa \alpha \theta$ ' $\eta \mu \tilde{a} s:$ Tox. 10) of extraordinary acts of friendship among their countrymen, and the story of Arsacomas and Mazaea is one of those offered up by Toxaris. Lucian thus represents the transmission of the story from East to West as occurring orally, told, soon after the events in question, by a Hellenised Scythian to a Greek from Athens. ${ }^{7}$

Of course, Lucian's dialogue is fictional and steeped in literary convention; the scenario in Toxaris does not necessarily tell us anything about how Lucian himself learned of the story (if he did not invent it outright). But it provokes some thoughts: not only about the authenticity of 'Toxaris' tale as Scythian 'oral' legend, but also to what degree the kind of oral transmission depicted in the dialogue is a viable model of the way non-Greek narrative traditions made their way into Greek culture. Unlike Stephens and Winkler, who acknowledge the possible oral origins of the tale but presume that the material reached Lucian and the Calligone-author in written form, Lucian depicts the oral intercourse between East to West as very much a living phenomenon in his own day. It is not impossible that Stephens and Winkler are right, but it remains an open question whether their theory, of an 'early' oral tradition eventually supplanted by written narratives, is inherently more likely than the Lucianic model of oral transmission.

As this discussion shows, the 'oral' part of the term 'oral transmission' can be understood in two ways. In the simplest sense, a story is orally transmitted when one person tells it to "another (or others), as Toxaris tells his tale to Mnesippus. We see examples of such narration depicted repeatedly in Greek and Latin literature from Homer onward, and Toxaris' narration " of his Scythian 'romance' has famous precursors in the works of Herodotus, Plato, Plutarch, the novels and countless others. Moreover, Greek and Roman culture in all eras retained a considerable oral dimension, and even among the educated elite of Hellenistic Alexandria or the Imperial East, where books and reading were an integral part of paideia, much intellectual interaction took place through speaking and listening, whether in recitations, rhetorical performance, symposiastic discussion, or

7 Moreover, Toxaris reveals himself to have been a partial 'eyewitness' to the events at the end of the tale - he had fought alongside Arsacomas in the final victory (Tox. 54). On Toxaris, see Braund 2004. 
philosophical education, as a glance at texts such as Plutarch's Table Talk or Philostratus' Lives of the Sophists shows. ${ }^{8}$

Orality in this sense, then, refers primarily to the mode in which stories were related to others, and says nothing about how the stories themselves arose. In fact, much of what was passed on in oral form in Imperial circles was originally written down. A perusal of Aulus Gellius' Attic Nights or Athenaeus' Sophists at Dinner reveals speakers who spout anecdotes explicitly culled (and cited) from their reading; similarly, a speech delivered orally to an audience by, say, Aelius Aristides, would most likely have been composed beforehand as a written text.9 The term 'oral transmission', however, often implies that there is something 'oral' about the origins and nature of the transmitted content itself: that it was not only 'performed', but also composed orally and circulated solely via oral channels. ${ }^{10}$ The Homeric epics in the early stages of their development are naturally the most familiar model, but more relevant for our purposes are folktales or novelle that, like the Toxaris tale (according to Stephens and Winkler), were 'first popularised in legend' before eventually finding their way into written texts, where they often retain markers of their traditional, popular and oral origins.

In this chapter, I address both of these aspects of oral transmission (although they naturally overlap). I begin by establishing the influence of oral traditional tales upon certain types of Greek and Roman narrative fiction and then move on to consider the modes of oral transmission the people, the contexts - by which such content might have been disseminated. The evidence for cross-cultural transmission introduced there leads into a final section, where I return to the question of content and consider the kinds of specifically 'Eastern' stories that might have been orally transmitted to the West.

\section{Ancient popular narrative and oral tradition}

The study of Greek literature's debt to oral tradition has naturally focused on the era of nascent literacy - the archaic and early classical periods.

8 Cf. Harris 1989: 225-6; Thomas 1992: ch. 6; Valette-Cagnac 2007.

9 Not to mention recitations or public readings of literary texts. Cf. Goldhill 2009 on the complex interplay between literacy and oral perfomance in the Second Sophistic, and the growing body of scholarship interested in the interconnections and mutual influence of orality and textuality in the Roman Empire (e.g., the articles in Rimell 2007 on the ancient novel).

1o On the ambiguities of the term 'oral transmission', see Finnegan 1974 and 1988: 'the stricter definition of being transmitted unchanged orally for generations, besides being largely speculative, is difficult to apply and bedevilled by romantic overtones' (I988: 6I). 
Homer and Herodotus are the chief figures here, but I should emphasise that for my purposes, their status as oral performers and/or composers is less important than the fact that much of their material was taken from oral sources." Herodotus' Histories, in particular, is an invaluable (and unique) compendium of legends, folktale-influenced anecdotes and novelle from all over the Eastern Mediterranean; moreover, Herodotus repeatedly emphasises the oral nature of his sources, and the tales themselves often retain signis of oral composition and style. After Herodotus, such explicit evidence for oral storytelling is much harder to come by. Over half a century ago, however, Sophie Trenkner presented a strong case for the influence of popular novelle on Classical Athenian literature - especially comedy and Euripidean tragedy - and recently scholars such as Graham Anderson and William Hansen have sought to demonstrate the underlying folkloric bases of a wide range of ancient texts, from myths to romances, in periods well after the spread of literacy. ${ }^{12}$

For the Hellenistic and Imperial eras, Greek and Latin prose narratives are among the most important witnesses to the continued influence of oral traditions, particularly those thought to have been written for popular (as opposed to elite) audiences. ${ }^{13}$ Notable examples are Greek fictional biographies (the Life of Aesop, the Alexander Romance and Secundus the Silent Philosopher), Jewish legendary narratives (Tobit, Daniel and Joseph and Aseneth), the Christian Apocryphal Acts of the Apostles, and the Latin novel Apollonius, King of Tyre. ${ }^{14}$ Popular texts such as these share several features that are also characteristic of oral narratives: anonymous authorship, an unrefined style, content incorporating folktale motifs (riddles, tricksterlike activity, adultery) and an episodic structure, focused on an individual and showing signs of having been compiled from several different sources. ${ }^{\text {Is }}$ While such features do not guarantee oral origins, they certainly increase their likelihood. ${ }^{16}$ Lawrence Wills, for instance, takes the closeness

II Aly 1921; Hansen 1997. On the question of whether Herodotus himself was an oral performer of his stories, see e.g., Stadter 1997 with previous scholarship at I3, n. I.

12 Trenkner 1958; Anderson 1984, 2000, 2006; Hansen 2002.

13 For a definition and discussion of ancient popular literature, see Hansen 1998.

I4 The extant versions of all of these texts date from the Imperial period, with the exception of Tobit and Daniel (which are Hellenistic), although Aesop and Alexander, at least in some form, are clearly pre-Imperial. Tobit, moreover was likely originally written in Hebrew; on its complicated transmission, see Fitzmyer (2003) and Weeks et al. (2004).

is For discussion of the Greek texts, see in general, Selden 2010; for specific texts, see Gallo 1996 on Secundus and Alexander, Konstan 1998 on Alexander, Thomas 2003 on the Acts of Peter, Jouanno 2009 and Karla 2009b on Aesop and Alexander, and. On Apollonius, see Perry 1967: 294-324; Ruiz Montero 1983; Panayotakis 2007.

${ }^{6} 6$ In fact, recent work on popular texts (Konstan 1998 calls them 'open texts'; Jouanno 2009 uses 'patcliwork novels'; Selden 2010 refers to 'text networks') has shown that they are characterised by 
of Tobit's plot motifs with that of known oral folktales and its author's habit of 'incorporat[ing] insertions without smoothing over the transitions' (214) as signs that the written novel has 'evolved' out of an oral tale (9I). ${ }^{17}$

It is difficult, however, to prove definitively that a given episode in a written text is indebted to oral tradition, because stories circulating orally in popular milieux leave traces only when they make their way into written texts, and there is thus little, if any, independent evidence of their existence. One method commonly employed to circumvent this problem involves comparing the ancient written version with analogous oral tales recorded more recently and in a wide enough range of locales to qualify as 'international'. The premise here is that if significant structural similarities between an international folktale and an ancient story are detected, one can conclude that the ancient version (even if it is the earliest recorded) most likely derives from a pre-existing traditional tale, rather than acting as the 'source' for later variations. For example, Hansen has argued persuasively that an episode in the Life of Aesop where Aesop proves that his master Xanthus' dog, rather than his wife, is the one who 'truly loves' him, is a version of the international tale known as Best Friend, Worst Enemy, in which a man, when asked to produce his best friend and worst enemy, demonstrates that the former is his dog, and the latter his wife. ${ }^{18}$ Unless one accepts the extremely unlikely possibility that all of the modern oral versions somehow derive from the Life of Aesop, one can plausibly hypothesise that the novel version is but one, written, instantiation of a longstanding oral traditional tale that was circulating in antiquity before the author of Aesop adapted it. ${ }^{19}$ The method needs to be employed with care, but given what we know about the remarkable persistence and longevity of orally circulating tales and the nature of popular narrative, ${ }^{20}$ the premises on

the narrative fluidity and lack of fixity that we associate with oral narratives even when they circulate in writing; each 'performance' or transcription results in a different text, depending on the context for which it is produced.

17 Wills I995. The same goes for Daniel I-6, which Wills believes is 'likely derived from oral legends of the pious heroes, legends that circulated independently in the fourth to third centuries BCE in the eastern Diaspora' (38). Cf. Braun 1938: 44-104 on the transformation of the Potiphar's Wife story 'from the novella or legend [Genesis], by way of the popular romance [Testament of Joseph], to the rhetorical romance [Josephus' Jewish Antiquities]' (IO4).

I8 Aarne-Thompson 921B; Hansen 2002: 49-54. Hansen's book, to which this section is deeply indebted, offers specific arguments in support of this method (often taken for granted by practitioners), as well as the persuasive demonstrations of its validity, through an impressive comparison of nearly a hundred examples of ancient tales with their international folkloric analogues. Cf. the remarks of Walter 1998 on the folkloric bases of medieval literature.

19 The presumption is that the tale proceeded afterwards to circulate orally in popular milieux independently of the ancient written version.

20 Cf. the remarkable case of The Poor Man of Nippur, an Assyrian cuneiform version of The Poor Man Cheated of His Oxen (Aarne-Thompson 1538), discovered in 1955 and dating to $c .700$ BCE (but 
which it is based are credible, and I take it as a working hypothesis that ancient stories evincing strong parallels with recognised international tales most likely originated in an oral milieu. ${ }^{2 \mathrm{I}}$

Although ancient popular novels frequently incorporate and adapt oral folktales and novelle, it would be wrong to call the novels themselves 'oral literature' or 'oral texts'. No single oral narrative was the likely inspiration behind any of the novels; nor are the written versions we possess mere transcriptions of a series of episodic oral anecdotes and tales. For example, even though many individual episodes in the Life of Aesop can be connected to traditional folktale types, ${ }^{22}$ the earliest version of Aesop we possess (Vita $G$, first century CE) is clearly the product of writing; the anonymous author has compiled and adapted a variety of Aesop traditions and episodes into a semi-coherent whole. ${ }^{23}$ Rather than 'oral literature', then, we might call Aesop 'oral-derived' in that it owes much to oral traditions, but remains a written text.

Nevertheless, it is important to recognise the essential fluidity between oral and written that characterises the formative history of the traditions contributing to popular novels. ${ }^{24}$ While it might be possible to trace the moments when particular strands of the 'oral' Aesop tradition were written down, or when a complete version of Aesop was put together, ${ }^{25}$ there is no reason to assume that the act of fixing part of the tradition in writing

possibly copied from a much older Babylonian text). The tale is found in substantially the same form in the Arabian Nights and in oral versions recorded as late as the 1940s, almost three millenia later. See Gurney 1956 and 1972; Jason and Kempinski 198I.

21 Criticism of this method has focused on the possible oral, folkloric origins of the Cupid and Psyche story in the Metamorphoses. Fehling 1977 is the most vigorous sceptic, but see also Dowden 1985 on Scobie 1983 and Schlam 1993 (referred to with approval by Zimmerman 2004: 12). Defenders include Swalın 1955; Walsh 1970: 190-223; and Hansen 2002: 100-14.

22 Konstantakos 2006 on Aesop 75-6; Hansen 2002: 49-54 (Aesop 44-50; discussed above); 234-40 (Aesop II-64); 25I-5 (Aesop I3I). Moreover, a significant section of the Aesop shares its plot with that of Ahiqar, a very old Near Eastern legend (see below). Another possible parallel proposed by Hansen is less convincing: 2002: 97-9.

23 As Holzberg 1993, Merkle 1996, and Konstantakos 2006 have shown, the Life as we have it has been assembled with a certain amount of artistic skill.

24 Thomas 2003: 14, notes that it is often impossible to tell 'whether one text is appropriating another by means of textually based procedures or by knowledge from memory ...' and that 'the distinction between textual process and memory, rather than written source and oral source, might be closer to the conceptual framework of the authors and audiences of the ancient world' (I4). For Thomas, the Acts of Peter is the result of reworking both written sources and traditions incorporated via memory.

25 E.g., Adrados 1979: 106; 'a changing, oral tradition' dating as far back as the fifth century BCE was only 'fixed in writing for the first time' in the first century CE; M. L. West 1984: 122: the Samian part of the Life dates from the mid-fifth century BCE; Perry 1962: 332-4, on the biographical information recorded in Demetrius of Phalerum's late fourth-century BCE collection of Aesopic fables. It also seems clear that various episodes underwent considerable change as time went on - e.g., those involving Xanthus are set in a Hellenistic milieu but could have been adapted from anecdotes told in earlier eras. 
put an immediate stop to oral activity, or even to the production of other written versions. ${ }^{26}$ One should thus imagine multiple clusters of Aesop lore, simultaneously circulating orally and in writing, perhaps even re-entering oral tradition from written texts. ${ }^{27}$ The episodes, novelle, anecdotes and motifs embedded in the written texts of ancient popular narratives most likely derive from a complex blend of oral and written sources, possibly arising from different cultures and in different eras. ${ }^{28}$ We may not be able to recover, reconstruct, or date these traditions with any precision, but we should not discount the likelihood of their influence.

\section{Sophisticated literary adaptations of popular oral tradition}

In addition to such oral-derived popular narratives, several more sophisticated literary novels - e.g., Petronius' Satyrica, Apuleius' Metamorphoses, Lucian's Lover of Lies - show close, yet fundamentally different, connections to the world of oral storytelling. On the one hand, the tales included in these texts are generally popular, or 'low', in nature - 'Milesian' narratives involving magic, the supernatural, sex and violence - and have striking analogues in folk traditions from around the world. ${ }^{29}$ The novelle in the Satyrica, such as the Widow of Ephesus and the Pergamene Boy, are well-known examples, ${ }^{30}$ while the Metamorphoses as a whole has been seen as reflecting 'the same wide field of oral folk-narrative' as the Life of Aesop; ${ }^{31}$ a similar relationship to popular accounts of the supernatural

26 Anderson 1996; Winkler 1985: 279: ‘ $\ldots$ we have to posit a repertoire of episodes, featuring Aesop as a fixed character, that undergoes continuous adaptation, contraction, and expansion at the hands of numerous storytellers'. A good account in Hägg 1997: 177-86. At some point, of course, stories about Aesop stop being told and he becomes primarily a written phenomenon, but this moment need not coincide with that of the writing down of the Life. On this, see now Kurke (2011), I-49.

$27 \mathrm{Cf}$. Wills I995 on how oral legends and folktales underlying Tobit and Daniel have 'been processed through a new medium' and combined with written texts and tales (214); Konstantakos 2006 on the interplay between oral and written in the circulation and development of 'adultery tales' in antiquity.

28 The same could be said, more or less, for the Alexander Romance, Secundus and the Apocryphal Acts.

29 For a broad definition of 'Milesian' tales, see the selection in Ferrari 1995. On the genre, see, among many treatments, Harrison 1998a, Jensson 2004: 245-30r and Bowie in this volume.

30 On Petronius' novelle, see Walsh 1970: 10-17 and Anderson 1999.

31 Winkler 1985: 283; cf. Scobie 1975: 35: 'a repository of folktales'. A specific example: Konstantakos 2006: 589 attributes the parallels between the Life of Aesop 75-6 and Apuleius' Tale of the Tub episode (9.5-7) to their shared use of 'motifs and episodes [drawn] from the rich field of ancient folk narrative'. Even the primary narrative of the Metamorphoses, the Ass-Tale which Apuleius took over from the Greek Metamorphoses, is closely tied to oral folk traditions concerning witchcraft and metamorphosis (Scobie 1975: 26-46; 1983); indeed, 200 years later, legends of witches transforming travellers into beasts of burden were still being told orally in Italy, as attested by Augustine (De civ. dei 18.18$)$. 
could be claimed for the Lover of Lies. ${ }^{32}$ The tales in these works, however, rather than being directly incorporated into the plot or adapted to the main characters (although this does occur, especially in Apuleius), are usually stand-alone stories embedded within the narrative; significantly they are often depicted as told by one character to another or others, as if the author wished to emphasise their oral nature. ${ }^{33}$ All three authors thus manage to mix 'high' literary style with the 'low' subject matter associated with popular culture and oral circulation.

As I noted in my discussion of the Toxaris tale, even when scholars accept the oral or folkloric origins of a story found in elite texts, they tend to assume that it must have reached its respective author via written sources. ${ }^{34}$ It bears repeating that, in the absence of evidence, the transmission of the tale to the author in question could just as easily have been oral. ${ }^{35}$ In fact insisting upon an 'either/or' choice between oral and written transmission potentially misrepresents the complexity of how novelle made their way into sophisticated literature. ${ }^{36}$ Consider the well-known 'Milesian' tale, The Widow of Ephesus, which Petronius has Eumolpus tell to a group assembled on a ship (Satyrica III). There are two other, roughly contemporary, ancient versions: one in the fables of Phaedrus, a Greek freedman writing in Latin ( $A p p$. I 5), and another in Greek from the Life of Aesop (129). The relation between these three texts, and the origins of the tale, have been fiercely debated: leading contenders as Petronius' 'source' are Aristides' (lost) Milesian Tales or a n earlier collection of Aesopic fables. ${ }^{37}$ But the fact that oral versions of the tale have been collected from as far afield as nineteenth-century Russia and twentieth-century North Africa, ${ }^{38}$

32 The Lover of Lies features many tales (like the Sorcerer's Apprentice: $33-7$ ) for which striking analogues can be found, not only in later tales told in both Western and Eastern cultures, but also in variant forms in other ancient texts - facts pointing to oral circulation. See now Ogden 2007; on ancient $\therefore$ ghost stories, Felton 1999.

33 Salles 1981. There is some speculation that Aristides' Milesian Tales framed its narratives in a similar way: Harrison i998a.

34 E.g., Rademacher 1927 on the Hyperborean Mage story in Luc. Philops. I3-Is (on which see now Ogden 2007: 105-29).

35 Thomas 2003: 14: 'For less exact degrees of "dependence", however, it is nearly impossible to distinguish whether an author was using an oral or written source... Citing a written text by memory, whether from a text read or heard, and citing an orally circulating tale would look the same, and perhaps, for the ancient world, have nearly the same import.'

${ }_{36}$ Cf. Finnegan 1988: 57: 'the relation between oral and written forms need not just be one of parallel and independent coexistence, far less of mutual exclusion, but can easily exhibit constant and positive interaction. Indeed it becomes clear that this sort of situation may well be just as normal and characteristic a setting for oral literature as the extreme type A "primitive" and non-literate culture posited in the classical dichotomy.'

37 On Demetrius of Phalerum's collection of Aesop's fables as possible source, see Perry 1962: 329-30.

${ }_{38}$ Ure 1956; Hansen 2002: 266-79. 
coupled with the existence of these three ancient variants (in texts with close ties to popular culture), strongly suggests that the tale was circulating orally before, during and after Petronius' time. ${ }^{39}$ And even if an oral version of The Widow of Ephesus had been recorded in writing by Aristides or some other author, the story itself in all likelihood continued to circulate orally in antiquity after it had been written down for the first time. ${ }^{40}$ There is no reason to presume that Petronius encountered the story in writing; he could very well have heard it told, or even read and heard different versions at different times.

In the Metamorphoses Apuleius even provides some hints that the practice of recording 'living' oral traditions was current, through his repeated references to adaptations of oral fabulae into literary form. ${ }^{41}$ At 6.25 , after hearing the old woman tell the Cupid and Psyche tale, Lucius famously regrets 'not having notebooks and a pen (pugillares et stilum) to write down such a good story (tam bellam fabellam praenotarem)' and at 6.29, Charite proclaims that her escape on donkey-back 'will be seen and heard in stories and though unsophisticated will be perpetuated by the pens of the learned' (uisetur et in fabulis audietur doctorumque stilis rudis perpetuabitur historia...). Later, at 8.I, the slave begins his report of the tragic death of Charite with the words: 'I shall tell you (referam) what happened from the beginning, events which the more learned (merito doctiores), those to whom fortune has given pens (stilos), can wrap in paper as an example of history (in historiae specimen chartis involuere).' Apuleius thus not only depicts a series of oral tales as being told within his narrative frame, but also has the narrators themselves anticipate the transformation of these originally oral narratives into written texts. Again, as with Lucian's Toxaris, these examples do not prove that the tales in question had been transmitted orally to Apuleius, but they do show that the transfer of an entertaining narrative from oral to written form was envisaged as a contemporary phenomenon.

There is some evidence that other Imperial authors demonstrated a similar interest in collecting, publishing and adapting orally circulating stories and legends. One such case is Xenophon of Ephesus, whose Anthia and

39 Hansen 2002: 272, who further notes, "because the novella has been so frequently anthologised it has probably reentered oral tradition sporadically from literary sources, so that the tale has been transmitted both orally and literarily'.

40 Many modern 'urban legends' continue to be told orally as 'true' well after they have been adapted in a literary work: for example, a variant of the legend known as The Surpriser Surprised appears in Carson McCullers' The Heart is a Lonely Hunter in 1940, yet was still being told as a 'real' contemporary event in the 1970s: Brunvand 1981: 148-9.

41 Fowler 200I. As Bitel 2001 notes, Apuleius consistently uses fabula to denote oral discourse; $\mathrm{cf}$. his list at $145-6$, n. 26. 
Habrocomes has been the subject of much scholarly debate regarding its relation to orality. ${ }^{42}$ Unlike the popular works listed above, Xenophon's novel is not anonymous (although some see 'Xenophon' as a pseudonym) and has a more complicated, albeit still episodic, plot, focused on two protagonists - the Liebespaar - rather than one. Nevertheless, it exhibits popular stylistic and formal features that set it apart from the other canonical.Greek romances, for which indications of direct oral influence are generally lacking. ${ }^{43}$ As we have noted, such features need not point to an orally composed or circulating tale as the written text's immediate source, but they do suggest the possibility of an oral, folkloric background at a further, yet still reasonably close, remove. Moreover, some of the content also bears traces of oral origins. Several episodes are very obviously based on folktale plots, especially Near Eastern 'court' tales, such as the two variants of the Potiphar's Wife tale (in which Habrocomes is approached by Manto and Cyno respectively). Two other stories are self-standing novelle in a Milesian vein: one concerning star-crossed lovers, the other a Sicilian fisherman and his mummified wife. ${ }^{44}$ The best explanation of this hodgepodge is not that Xenophon has written down a version of a single orally composed narrative, as James O'Sullivan has argued,45 but rather that he has incorporated a variety of oral tales into his ideal love novel, with uneven results. The stylistic peculiarities can be explained, as Consuelo Ruiz Montero does, 'by postulating that Xenophon is attempting to retain the flavour and cadences of the originally oral rhythms of such tales. ${ }^{46}$

In support of this hypothesis, Ruiz Montero points to two other contemporary, albeit non-fictional, works that evince similar stylistic characteristics and seem also to be adapting oral material, primarily of a local nature: Plutarch's Narratives of Love and parts of Pausanias' Periegesis. ${ }^{47}$ Like Xenophon, these authors employ 'a rhetorical mimesis' of the oral 'style' in which the stories were originally transmitted, and Ruiz Montero concludes

42 The connections claimed by Anderson 1984 are distant indeed; while there is no doubt that certain plot motifs and themes may ultimately have originated in oral tales, the degrees of separation are far greater than in the popular or the 'Milesian' novels.

43 Often noted, e.g., by Reardon 2004; Ruiz Montero 2003a: 44: 'kai-connectives, historical presents, parataxis, and stereotyped formulae ... continual repetitions of all sorts at different levels, the lack of motivation in the plot, the contradictions, the information gaps, the break-neck pace of the different episodes, the psychological superficiality of its characters (divided into good and bad) who appear in droves and are all given names'.

44 Xen. Anth. 3.1-2; S.1. See Ruiz Montero 1996: 64.

45 O'Sullivan 1995: although his position is more nuanced than later critics have assumed.

46 Ruiz Montero 2003a.

47 Ruiz Montero 2003b; examples of such tales in Pausanias include the ghost story at 6.6.7-1I and the love story of Coresus and Callirhoe at 7.21.I. Cf. Ruiz Montero 2003c on 'popular' style in Greek literature more broadly. 
that this correspondence intimates that Xenophon's material could possibly have derived from local, oral traditions in Greece and Asia Minor. ${ }^{48}$ The relevant point here, however, is that such works furnish additional evidence for a flourishing body of orally circulating tales in the Imperial period 49 - not only folktales, fables and 'Milesian' tales, but also stories of the supernatural and local legends of love and adventure. Such oral traditions find their way into popular literature, but also become the object of interest for certain elite intellectuals - novelists, historians, philosophers who receive, collect and write them down, thus transmitting them to an even wider audience.

\section{Contexts for oral transmission and performance}

In what contexts and from what sort of informants, then, might such oral tales have been collected? And by whom were they disseminated, or transmitted to others? Scholars of ancient oral traditions tend to concentrate on figures who could have acted as contacts between popular and elite circles. One such group consists of local informants, who would have been the primary sources for Pausanias and other 'collectors' of local traditions, or guides at various tourist sites, such as those disparaged by Lucian in Lover of Lies and by Plutarch in On the Pythian Oracles. ${ }^{50}$ Somewhat more elusive are itinerant storytellers - fabulatores or aretalogoi-disseminating popular folktales and legends as they moved from city to city; the evidence for their existence, however, is extremely scanty. ${ }^{\text {II }}$ Women are also often mentioned as preservers of oral traditions in antiquity, whether in their capacity as child-rearers - nurses telling children Lamia-tales or Märchen (like Cupid and Psyche) - or as domestic workers - weavers singing myths or songs to while away the time. ${ }^{52}$ An example outside of a strictly female milieu is found in Xenophon's Anthia and Habrocomes, where Habrocomes and Hippothous, as they are drinking at an inn, hear of Anthia's travails

${ }^{8}$ Quotation from Ruiz Montero 2003a: 60; on Xenophon and local history, 57. On the connections between local history and romance in the Hellenistic period, see Lavagnini 1921 and Whitmarsh 2010c: 402-4; for Herodotus, Luraghi 2001.

49 Ruiz Montero 2003b: 23I; 2003a: 47: 'the circulation of motifs and folk-tales amongst different cultures and countries was profuse'.

50 Pretzler 2005, Ruiz Montero 2003a, Jones 2001; Luc. Philops. 4; Plut. Pyth. Or. 2 (395A).

II Salles 1981; Scobie 1983: 11-16.

s2 Scobie 1983: 16-30; Anderson 2006: 56-8; Ziolkowski 2002; Heath 2011. Chariton's Callirhoe has been connected with oral performance, a written text which, as Hägg 1994 has suggested, was read out loud to groups, and was designed to be performed in such a manner; $S$. West 2003a envisages women engaged in communal household tasks such as weaving as an ideal audience for such readings. 
at :Tarsus (which have already passed into local lore) from an old woman named Chrysion (3.9). Another example of a public, impromptu narrator of recent events is the slave who describes the tragic end of Charite and Tlepolemus to his compatriots in the Metamorphoses (8.I-I4), and one could envisage how similar scenarios involving skilled, non-professional storytellers in various contexts might have contributed to the creation and diffusion of local legends.

As these" last examples illustrate, our main evidence concerning context often comes from the same written texts that preserve the novelle themselves. ${ }^{53}$ As I mentioned above, the tales embedded in the narratives of the novels invoke the world of oral storytelling not only by replicating its content but also by re-creating the scenarios in which such tales might have been told. The majority of these storytelling moments occur in one of two circumstances: during travel (on the road, at inns, aboard ship) and at private gatherings, such a banquets or symposia, hosted by a member of the elite. In the first category we can include the two stories from Xenophon and Apuleius mentioned in the last paragraph, as well as Aristomenes' tale in the Metamorphoses, Eumolpus' Widow of Ephesus and Pergamene Boy in the Satyrica, ${ }^{54}$ and those stories in Ps.-Lucian's Amores that are told during a sightseeing trip to Cnidus. Banquets are the scene of Thelyphron's tale in the Metamorphoses and Niceros' werewolf account in the Satyrica (61.662:I4); a less formal get-together is the one at Eucrates' house that prompts the competitive supernatural tale-telling in Lover of Lies. ${ }^{55}$ Another feature that characterises many of these stories is their insistence on truth; despite their traditional origins, almost all are related as something that really, happened; whether to the narrators themselves, or to someone they know. ${ }^{56}$ The prevalence of these two types of tale-telling scenarios in ancient fiction most likely reflects the real-life importance played by travellers and social gatherings in orally introducing entertaining narratives from elsewhere to 'Greece'. As an example, I want to take a look at a text that provides some particularly suggestive illustrations of how this might have worked in practice: Plutarch's On the Decline of Oracles, one of a series of his dialogues

53 Dupont 1999: 179-204. Tarrant 1997: 191, notes that the stories in Lover of Lies 'are amusing primarily because they are rooted in the familiar realities of story-telling'.

s4 On Eumolpus as storyteller, see Beck 1979.

ss Plato's Symposium, of course, is an early example in which such gatherings are depicted as the backdrop not only for philosophical discussion, but also for the exchange of narratives.

56 Cupid and Psyche stands out here, both as a tale told in an unusual consolatory context by a woman to a girl, and for its 'fairy-tale'-like content. On the difficulty of categorising oral tales as 'belief legends', see Dégh 1996. 
(Amatorius, Table-Talk, etc.) that offer a vivid image of Imperial elite society. ${ }^{57}$

One of the stories told in Decline, which depicts a gathering of intellectuals at Delphi in 83/84 CE, reports the death of Pan, and is an excellent ancient example of an allegedly 'historical' account that turns out to be derived from a widely known folktale. ${ }^{58}$ The story is told by Philip, who has, in typical urban legend fashion, not witnessed it himself, but heard it from a 'friend': his teacher Epitherses. Epitherses was on a ship bound for Italy; as it passed the island of Paxi, a voice was heard 'loudly calling Thamous, an Egyptian pilot, not known by name even to many on board'. After being called three times, Thamous responded; the voice then said, 'When you come opposite to Palodes, announce that Great Pan is dead.' When they reached the Palodes, Thamous did as he was told, and there 'was a great cry of lamentation, not of one person, but of many [...] The story was soon spread abroad in Rome and Thamous was sent for by Tiberius Caesar, who became so convinced of the truth of the story that he caused an inquiry and investigation to be made about Pan.' The tale, which was to gain much notoriety among Christian authors for its intimations of the death of paganism, is an adaptation of a folktale, recorded in a wide range of locales, in which an enigmatic injunction to travel somewhere and announce the death of an unknown figure incites the unexpected lamentation of a group of beings (fairies, cats, etc.); the parallels even extend to the odd alliteration (Paxi, Palodes, Pan) and the traditional folktale repetition of three.59

In the dialogue, this folktale has become a historical event, dressed up with realistic detail and references to 'real' people. Moreover, it is depicted as a living oral tradition, told by Philip to an enthralled group of at least six others, including Plutarch's brother Lamprias and his teacher Ammonius. Does this represent a reasonable approximation of the kind of story that might be told on such occasions? On the one hand, it is difficult to imagine that the stylistically homogeneous and intricately complex language of the speakers in Plutarch's dialogues approximates actual conversation; Plutarch's dialogues present an unabashedly idealising portrait of his own intellectual circles. But the literary dialogue had always required a certain suspension of disbelief from its readers; after all, a common conceit (à la Plato) is that the entire text, replete with embedded stories and speeches,

57 On the verisimilitude of Plutarchan dialogue, see Tarrant 1997; in broad terms, I share his belief that '... much of what Plutarch wrote in dialogue form was modelled on types of oral learned activity, from after-dinner discussion and entertaining narratives to the more serious philosophical debates' (186).

58 Hansen 2002: 131-6. 59 Borgeaud 1983. 
is the transcription of a narrative being told to another listener. ${ }^{60}$ The Death of Pan, at any rate, is different from the long intricately argued philosophical speeches in Plutarch's dialogues; like Eumolpus' Milesian tales in the Satyrica, it is the standard length of a novella, about a page (419B-D), and for all of its learned accoutrements betrays a basic folkloric structure. And while we do not know where the story originated, or how it made its way. into elite circles, the dialogue provides a glimpse of the way social gatherings functioned as venues for the introduction and oral transmission of such tales.

Travel also plays a large role in On the Decline of Oracles. Philip's story, or at least Epitherses' original, is a traveller's tale; although it is not told while travelling like the examples from the novels I mentioned above, it relates something that happened during Epitherses' travels (in this case, on a sea voyage).The literary association between travel and storytelling is as old as the Odyssey, and real-life travellers such as Herodotus and Ctesias or Iambulus and Euhemerus, whether reporting their own (invented?) experiences or relaying the legends and stories of other cultures that they had learned on their journeys, played a central role in the transmission and dissemination of legends and tales in antiquity. ${ }^{61} \mathrm{~A}$ good, if historically questionable; example focused on oral transmission is that of Solon, as depicted in Plato's Timaeus (20d-26d), who brings back the story of Atlantis from Egypt to Athens, where it is preserved orally down to the days of his great-grandson Critias.

The company in On the Decline of Oracles includes several men who are similarly returning to Greece after having travelled to far-flung lands in the spirit of philosophical and scientific inquiry: Demetrius the grammarian, who had journeyed to Britain 'for the sake of inquiry and observation

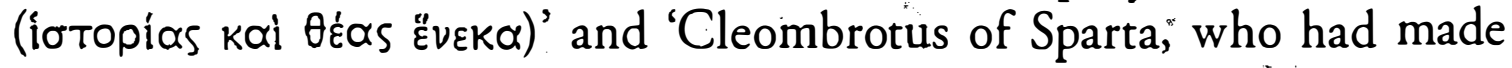
many excursions in Egypt and about the land of the Cave-Dwellers, and had sailed beyond the Persian Gulf; his travels were not for business, but he was fond of seeing things and of acquiring knowledge (

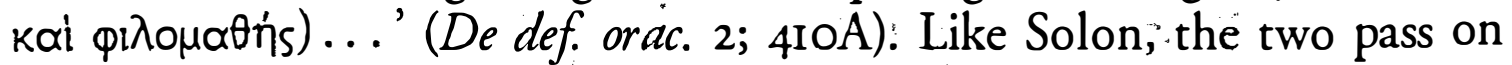
tales that they have learned in their travels from their interrogation of the non-Greek inhabitants of distant regions. Demetrius reports a story about the sleeping god Cronus he had heard from 'the people of an island' near

60 Tarrant 1997 believes that Plutarch's dialogic works 'emerged out of an intellectual background where the telling of long and detailed stories was routine' (189), but emphasises that the dialogues were neither meant to be read aloud nor transcripts of oral performance.

61 As these examples suggest, the association of travel narratives and fiction (or lies) is similarly well attested: Romm 1992; Whitmarsh 2010c: 408-9. 
Britain $(28 ; 420 \mathrm{~A})^{62}$ and the dialogue begins with Cleombrotus relating 'a story worthy of special consideration' that Egyptian priests had imparted to him when he was visiting the shrine of Ammon in Egypt (2; 410B). Later on, at 42IA-B, Cleombrotus mentions another more exotic story that he had learned from 'a foreigner', who nevertheless spoke to him in Doric, '[in an area] near the Persian Gulf. What is striking in Decline is the depiction, not only of popular oral content (the Death of Pan) told in a lofty elite setting, but also of the oral transmission by travellers of foreign lore and narratives. ${ }^{63}$ It reflects a thriving Imperial traffic in oral narratives as well as a particular fascination with those originating outside of the Greco-Roman world.

We can see similar scenarios mixing oral tales, travel and foreigners elsewhere in Imperial Greek literature: dialogues like Lucian's Toxaris and Anacharsis (which feature Scythian travellers in Greece) or his Lover of Lies, in which the various Greek narrators tell of their meetings with Babylonians, Hyperboreans, Syrians from Palestine, Arabs and Egyptians. ${ }^{64}$ In another 'oral' genre, oratory, we find Lucian, in Heracles, reporting to his audience a conversation he has with a Celt about a painting of the hero; Dio Chrysostom, in his Trojan Oration, claims to reveal the 'true' story of the Trojan War he has learned from an Egyptian priest, and in his Borysthenitic Oration regales the Olbians with a cosmic Zoroastrian myth that he has heard from Persian magi. While some of these examples could be chalked up to literary convention, or self-conscious fictions (since voyages to foreign lands were almost de rigueur in biographies of Greek 'wise men' like Homer, Pythagoras and Plato), there remains a pervasive notion that travellers were an ideal means of transmitting knowledge from one culture to another.

${ }^{62}$ Cf. Sulla's tale of islands northwest of Britain (De facie 941a-945d).

63 Cf. Plut. De deo Socratis 576C; 577F-578A: Simmias returns from Egyptian Thebes 'full of all sorts of myths and foreign stories' learned from the priests there.

${ }^{64}$ Luc. Philops. II-12: 'a Babylonian man, one of the so-called Chaldaeans'; I3: 'when I first saw the

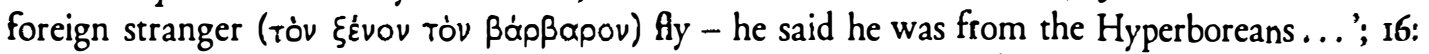
'Everyone knows about the Syrian from Palestine, the "sophist" regarding exorcism'; 24: 'at the same time turning the gem that the Arab gave me to the inside of my finger ... '; 3r: Arignotus relates how he has 'a great number of Egyptian books on such matters [ghosts, etc.]' and how he 'brought

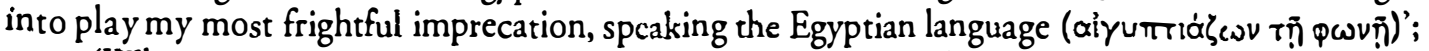
33-4: 'When I [Eucrates] was living in Egypt during my youth (my father had sent me travelling for the purpose of completing my education) ... But on the voyage up, there chanced to be a man with us from Memphis, one of the scribes of the temple (hierogrammateus), wonderfully learned, familiar with all of Egyptian paideia. He was said to have lived underground for twen ty-three years in their sanctuaries, learning magic from Isis.' Arignotus subsequently identifies this man as his own teacher, Pancrates! 
The travellers in these texts belong to a group of figures that we might term, after the folklorist Carl von Sydow, 'active bearers' of narratives, that is, particularly skilled storytellers that are crucial for the dissemination of oral tales from one culture to another. ${ }^{65}$ Although many members of a community may be familiar with a given tale, its successful oral transmission elsewhere tends to rely on contact between an 'active bearer' from the original community and an 'active bearer' in another area, who will spread the tale among his own community. So for each Greek traveller in the examples listed above, there is a corresponding 'native' who is just as essential for the transfer of knowledge, a (usually unnamed) Hellenised non-Greek, whether Egyptian, Celtic, Indian, Syrian, Scythian, etc. On occasion, it is the foreign figure who does the travelling; in Toxaris, the Scythian has come to Greece and tells his stories in Greek, as does the Egyptian priest Calasiris in Heliodorus' Aethiopica. Indeed, many of the novelists and writers themselves are Hellenised 'foreigners'; self-confessedly bi- or tri-cultural intellectuals - Lucian (Greek and Syrian), Apuleius (Greek, Roman, Punic); Iamblichus (Greek, Syrian, Babylonian), and Heliodorus (Greek, Phoenician, Syrian) - that have often been seen as possible conduits for the importation of 'foreign' cultural elements into Greek and Roman literature. ${ }^{66}$ It is important to remember, however, that these intellectuals are only the tip of the iceberg; in a world where so many people, voluntarily or not, found themselves travelling far distances (merchants, soldiers, performers, athletes, slaves, etc.) and settling in new surroundings, skilful transmitters of popular legends and lore from one culture to another could presumably be found throughout the Mediterranean. ${ }^{67}$

\section{Oral tales from the East?}

If the prevalence of Near Eastern, Scythian and Egyptian storytellers in Greek and Roman narrative suggests the possibility of a healthy exchange of legends and novelle between East and West, are there any specific 'Eastern'

65 Sydow 1948: 11-59.

66 Cf. Stephens and Winkler 1995: '14-17; Ramelli 2001 on Iamblichus and other Greco-Syrians like Bardaisan, Tatian (who wrote in Latin, Greek and Syriac), Sextus Julius Africanus, who was Palestinian and educated in both Greek and Syro-Aramaic, and Porphyry of Tyre, whose family was of Syriac origin, but studied Greek at Athens under Longinus. On Heliodorus' possible incorporation of Egyptian narrative, see Rutherford 1997, 2000a, 2002.

67 Much of what M. L. West 1997: 606-30 discusses concerning the 'dynamics of international transmission' between archaic Greece and Western Asia applies to later periods. For cultural contacts between Greece and Mesopotamia in the Hellenistic and Imperial periods, see Dalley and Reyes 1998. 
elements in written 'Western' narrative tradition that might give us some insight into the content of the cross-culturally transmitted tales? In a few rare cases, we can tentatively identify an originally Near Eastern or Egyptian oral tale that eventually, whether by oral or written means, made its way into Greek popular fiction. Perhaps the best example is the story of Ahiqar, which first appears in a late fifth-century BCE papyrus fragment written in Aramaic, but must be significantly older. In it, Ahiqar, an advisor to the Assyrian king Sennacherib, is falsely accused by his adopted son of treason, but is saved from death by the executioner, who is beholden to Ahiqar for an earlier favour. When Sennacherib misses Ahiqar and rues having killed him, the executioner reveals that he is still alive; Ahiqar goes on to save the kingdom, while his adopted son is given a stern lecture and imprisoned. ${ }^{68}$ The tale has gone through countless retellings, migrating to different figures and situations, and has been recorded in a variety of contexts, oral and written, up until at least the nineteenth century. In antiquity, the original Near Eastern story has been inserted, with very little modification, into the Greek Life of Aesop; the basic outlines of the tale also appears in the Jewish Tobit, the story of Croesus and Cambyses in Book 3 of Herodotus' Histories, and (possibly) the Greco-Egyptian fragmentary novel known as Tinouphis. ${ }^{69}$

While the ease with which Abiqar was transferred to different cultures is evident, we might note that the basic situation, in which a wise courtier is saved from an unjust execution, is dependent upon, and always remains within (even in the modern oral versions) a 'court' setting, in which the 'hero' has to negotiate the fickle decisions of an autocratic ruler. ${ }^{70}$ Another Near Eastern tale-type, Potiphar's Wife, that appears in Homer, Euripides and the Greek novels, is also a court-narrative, which features the hero at the mercy of a royal couple. If we may judge from the numerous examples of similar court-narratives preserved in Herodotus, the genre must have originated in the dynastic kingdoms of the Near East and Egypt, and likely continued to flourish as the Persian Empire gave way to Alexander, the Hellenistic kingdoms and the Roman Empire. Narratives such as that found in Secundus the Silent Philosopher, in which the hero outwits the Emperor Hadrian, might very well derive from Near Eastern

68 The papyrus breaks off before the king's remorse; later versions contain the whole story recounted here.

69 Kussl 1992; S. West $2003 \mathrm{~b}$. Once again, the variance and popularity of the story suggests a continued re-entry into popular narrative at different periods.

70 Thus even the Life of Aesop depicts Aesop as, rather curiously, the advisor of the (otherwise unknown) Babylonian king Lycorus in order to set up the Ahiqar narrative. 
oral traditions about clever courtiers that had been told for centuries. It is perhaps no accident that many of the Greek novels engineer scenarios in which their protagonists find themselves powerless in Egypt, Ethiopia, or the Near East at the courts of kings or satraps.

Another possible instance of Eastern oral influence on the novel is the opening episode of the Alexander Romance, in which Nectanebo, the last Egyptian Pharaoh, seduces the Macedonian queen Olympias and becomes Alexander's father. This almost certainly derives from an Egyptian legend and, while several scholars have posited a written version, there is nothing to rule out the possibility of an orally circulating story. ${ }^{71}$ According to Martin Braun, the two belong to a larger group of 'national' heroes around whom legendary traditions developed in the Hellenistic period, usually in response to foreign domination: e.g., Ninus and Semiramis (Syria/Mesopotamia), Sesostris/Sesonchosis (Egypt), Nectanebo (Egypt), Alexander (Greece and Egypt) and Moses (Jews). ${ }^{72}$ For each of these figures we possess a variety of (often contradictory) anecdotes and narratives - e.g., the very different accounts of Semiramis and Ninus preserved in Ctesias, Diodorus, Plutarch and the fragments of the Ninus Romance-and it is probably safe to assume that the popularity and importance of these historical figures spawned a host of oral as well as written legends. We could see a process similar to that outlined above for the Life of Aesop in which various oral migratory tales and motifs become attached to certain heroes, forming the basis for variant written narratives. ${ }^{73}$

We can thus tentatively propose two types of anecdotes or stories that have a high probability of originating in Egypt or the Near East and of circulating orally: those recounting the deeds of 'national' heroes and tales centred on a figure tied to an imperial court, like Ahiqar or Potiphar's Wife: The specific instances of these types that have made their way into Greek literature, the tales of Nectanebo and Ahiqar, retain both strong ties

71 So Stephens and Winkler 1995: 17 on the possible oral transmission of this tale. Perry 1966 on the other hand sees dependence on a novel, to which he links the fragmentary Nectanebo's Dream (in Greek); for the recently discovered Demotic version of this text, see Ryholt 1998a. Much of the first book of the Alexander Romance is of Egyptian origin, whether arising from oral tradition, as Merkelbach 1977 thought, or based on a novel, as claimed by Berg 1973. Other parts of the Alexander Romance have also been thought to have derived from oral traditions - cf. Merkelbach 1977: 68 on the so-called 'miracle letters'.

72 Braun 1938: I-43. Cf. Plut. Is. et Os. 24 (360B): 'However, mighty deeds of Semiramis are celebrated among the Assyrians, and mighty deeds of Sesostris in Egypt, and the Phrygians, even to this day, call brilliant and marvellous exploits "manic" because Manes, one of their very early kings, proved himself a good man and exercised a vast influence among them.' On Sesostris, see Ivantchik 1999, and Dieleman and Moyer 2010.

73 Novelised versions of this material, like Ninus or the less literary Sesonchosis, presumably represent one strand of this development. 
to folklore and their original Eastern setting. With these features in mind, we can look to other kinds of popular tales that might also preserve vestiges of their Eastern roots. Of particular interest are novelle in Greek and Roman narrative fiction concerned with supernatural or erotic content. The association of Egypt and the East with magic, divination and spirituality in the Greco-Roman worldview is especially strong (cf. Nectanebo in the Alexander Romance), and it is perhaps not a coincidence that Near Eastern and Egyptian characters abound in Greek and Roman supernatural tales. We have already mentioned the frequency of non-Greek characters in the magic tales presented in Lucian's Lover of Lies, and although Thessaly is the centre of witchcraft in the Metamorphoses, Apuleius still has room for stories featuring a Chaldaean astrologer (2.12) and an Egyptian priest able to raise the dead (2.28). The connection of the East with tales centred on love has been occasionally noted;74 Potiphar's Wife tales and adultery stories are well-known examples, ${ }^{75}$ and the romantic Persian stories in Herodotus, Ctesias and Xenophon's Cyropaedia can be compared to later tales such as that of the Babylonians Pyramus and Thisbe, and the famous story of the love between Seleucus I's wife Stratonice and his son Antiochus. ${ }^{76}$ Of course, the mere presence of Eastern characters in certain novelle does not demonstrate their Eastern origin; magic-tales, for example, might have traditionally featured an Easterner because they were commonly associated with magic, not because the tales themselves were originally from the East. Conversely, as the case of Ahiqar demonstrates, the basic plot of a court-narrative could be adapted to Western contexts quite easily, and one could imagine a similar migratory process occurring with motifs or episodes in national hero legends, which would become transferred to other figures by the time they show up in Greek or Roman literature.

Let me conclude with a brief comparison of two tales, one found in Lucian's On the Syrian Goddess, the other in the Life of Aesop. In Lucian's tale, Combabos, a nobleman at the court of Seleucus I, is sent on a mission

74 Whitmarsh 2010c: 404-6, with references.

75 Konstantakos 2006: 570-I: 'Generally, this type of adultery story seems to have been widespread in the ancient Near East.' While many have thought that they were originally Greek and passed into Arabic literature, 'it is generally impossible to prove the Greek provenance of any particular story' (571, n. 22).

${ }^{6}$ Mesk 1913; Whitmarsh 20roc: 405-6, on the 'interpenetration of Greek and Semitic erotic narrative' in this tale as well as others. This is not to suggest that the Greek novel, focused on the symmetrical love of a boy and a girl, originated in the East; despite the erotic focus of the tales listed above, there is nothing really comparable to the central plots of the Greek romance. Cf. Ruiz Montero 1996: 74-5. 
with the queen, Stratonice. ${ }^{77}$ Fearing that she will attempt to seduce him, he prudently castrates himself before setting out and deposits his 'treasure' with the (unknowing) king for safekeeping. When the inevitable accusation of sexual misconduct arises upon his return, Combabos asks for the valuables he had stored with the king to be revealed, thereby providing definitive proof of his innocence; his accusers are summarily punished. In the Life of Aesop (3-4); the mute Aesop is framed by two fellow-slaves as a thief; they eat all of the master's figs, but claim that Aesop, who cannot defend himself verbally, has consumed them. Aesop, however, provides definitive proof of his innocence by inducing himself to vomit, and then pointing to the fact that no traces of figs appear. The other slaves are forced to do the same, and the undigested figs that turn up reveal their guilt. ${ }^{78}$

The tales highlight somewhat different types of wisdom - the foresight of a world-wise courtier vs. the improvisatory brilliance of a lowly slave but their shared plot, in which the heroes, who are subject to a 'master', go to extraordinary and ingenious lengths to preserve themselves and get the better of their accusers, embodies a certain folkloric logic (reminiscent of the Abiqar story) that hints at oral, popular origins. ${ }^{79}$ Determining whether those origins can ultimately be traced to the Near East, Greece, Egypt; or India seems less important, however, than emphasising the ease with which the tale has been smoothly assimilated to two very different literary and cultural contexts, told both as an episode in the humorous Greek biography of a Phrygian slave and as a historical account of the Seleucid court embedded in an ethnographic account of Nineveh written in Greek by a self-styled 'native' Syrian. Whatever its roots, the story itself respects no national or ethnic boundaries.

Given the state of our evidence, it is extremely difficult to prove that a given plot, motif, or anecdote was transmitted from East to West via oral means, but what can be shown is that the oral circulation of stories was prevalent in all periods of antiquity, among the elite as well as the masses; that many of the same traditional, 'oral' tales are found in both Near Eastern and Greco-Roman literature; and that literary texts depict a lively traffic in oral storytelling between figures from different cultures. There is no doubt that Greek and Roman narrative owes a great debt to the

77 Luc. De Dea Syr. 19-27; see discussion in Lightfoot 2003: 384-417.

$7^{8}$ On this episode, see also Avlamis, this volume.

79 For later versions of the tale of Combabos, see Lightfoot 2003: 385-8. As she observes, scholars have long noted similarities with Abigar and other Persian court-narratives featuring a cunning vizier of a fickle monarch. The Aesop story corresponds to a tale that opens the Spanish picaresque novel Lezarillo de Tormes: Holzberg 1993: 1-2. 
storytelling traditions of Egypt and the Near East, and there is considerable evidence that borrowing did not end with Homer and Herodotus. But what seems more relevant and interesting for the study of ancient narrative is the existence, in the Hellenistic and Imperial periods of a thriving, mutual cross-cultural interchange of folktales, novelle and legends in a variety of oral and written forms throughout the Eastern Mediterranean. 